Metal-Catalyzed Asymmetric Synthesis and Stereoselective Reactions

\section{Key words}

palladium

thioether

polyfluoroarenes
C.-Z. WU, C.-Y. HE, Y. HUANG, X. ZHANG* (DONGHUA UNIVERSITY, SHANGHAI AND SHANGHAI INSTITUTE OF ORGANIC CHEMISTRY, P. R. OF CHINA)

Thioether-Promoted Direct Olefination of Polyfluoroarenes Catalyzed by Palladium Org. Lett. 2013, 15, 5266-5269.

\title{
Oxidative Olefination of Polyfluoroarenes Catalyzed by Palladium
}

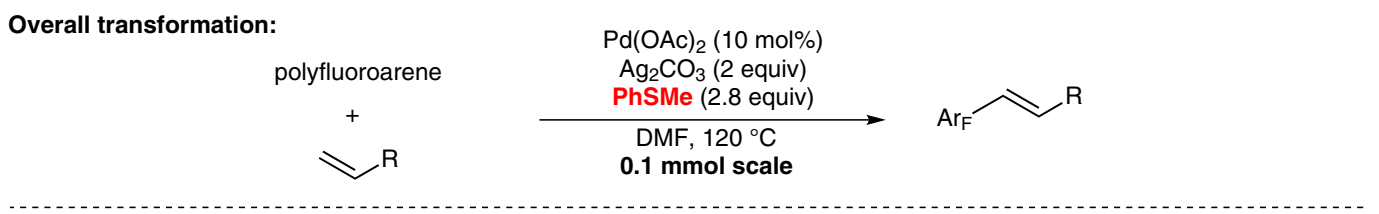<smiles>CC(C)(C)OC(=O)C=Cc1c(F)c(F)c(F)c(F)c1F</smiles><smiles>CCOC(=O)C=Cc1c(F)c(F)c(F)c(F)c1F</smiles><smiles>CCOP(=O)(/C=C/c1c(F)c(F)c(F)c(F)c1F)OCC</smiles><smiles>Fc1c(F)c(F)c(/C=C/c2ccccc2)c(F)c1F</smiles>

$80 \%$ yield, $E / Z=20: 1$<smiles>COc1c(F)c(F)c(/C=C/C(=O)OC(C)(C)C)c(F)c1F</smiles>

$80 \%$ yield, $E / Z=30: 1$<smiles>CCOC(=O)C=Cc1c(F)c(F)c(C(F)(F)F)c(F)c1F</smiles>

$74 \%$ yield, $E / Z=28: 1$

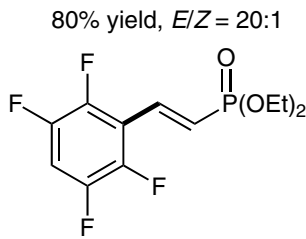

$72 \%$ yield, $E / Z=45: 1$<smiles>Fc1nc(F)c(F)c(/C=C/c2ccccc2)c1F</smiles>

$40 \%$ yield

\section{Competition experiment:}<smiles>Fc1ccc(F)c(F)c1F</smiles><smiles>C=CC(=O)OC(C)(C)C</smiles><smiles>CC(C)(C)OC(=O)C=Cc1c(F)c(F)c(F)c(F)c1F</smiles>
DMF, $120^{\circ} \mathrm{C}$

(1:1 product ratio)<smiles>Fc1c(F)c(F)c(/C=C/c2ccccc2)c(F)c1F</smiles>

Significance: The dehydrogenative Heck reaction represents a more environmentally friendly variant of the classic Nobel prize winning transformation, as it makes use of non-prefunctionalized substrates. Polyfluoroarenes are important structural motifs, and the development of new methods to incorporate them in an efficient manner is an important endeavor. The report represents a rare example of a thioether promoted $\mathrm{C}-\mathrm{H}$ functionalization of electron-deficient arenes.

SYNFACTS Contributors: Mark Lautens, David A. Petrone Synfacts 2014, 10(1), 0062 Published online: 13.12.2013 DoI: 10.1055/s-0033-1340448; Reg-No.: L15813SF
Comment: The authors report a palladium-catalyzed methyl phenyl sulfide promoted direct olefination of polyfluoroarenes. These previously 'unreactive' substrates undergo facile transformation with the specifically chosen sulfur-containing ligand. Products are obtained in good to excellent yields and with high $E / Z$ selectivities. A competition reaction between pentafluorobenzene and both styrene and tert-butyl acrylate show that there is no bias between electron-rich and electron-deficient olefins under the reported conditions. 